
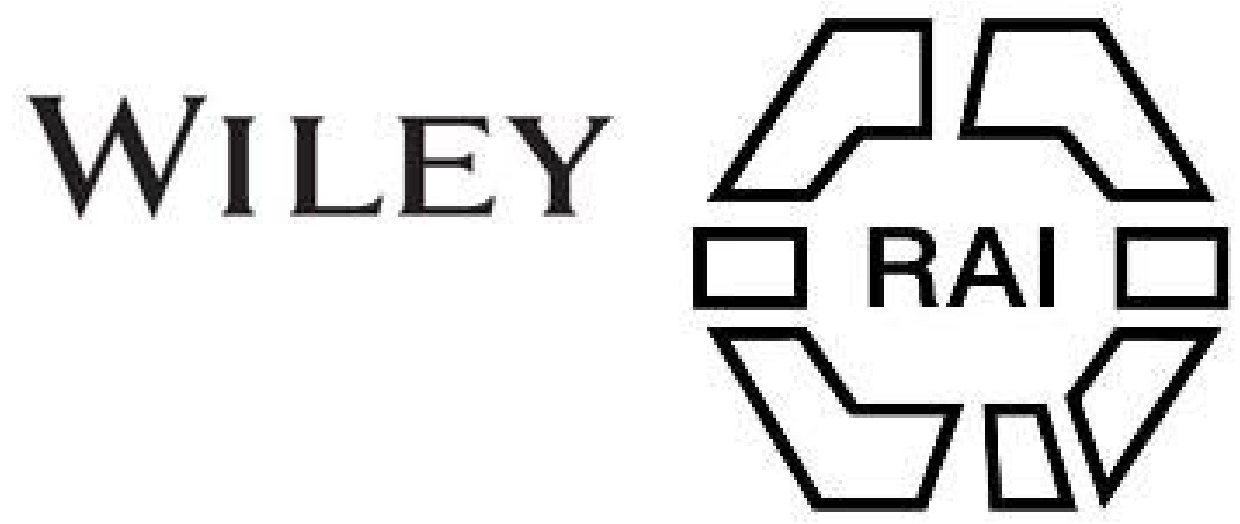

\title{
26. The Northern Babunda.
}

\section{Author(s): E. Torday}

Source: Man, Vol. 19 (Apr., 1919), pp. 49-55

Published by: Royal Anthropological Institute of Great Britain and Ireland

Stable URL: http://www.jstor.org/stable/2840660

Accessed: 26-06-2016 13:26 UTC

Your use of the JSTOR archive indicates your acceptance of the Terms \& Conditions of Use, available at

http://about.jstor.org/terms

JSTOR is a not-for-profit service that helps scholars, researchers, and students discover, use, and build upon a wide range of content in a trusted digital archive. We use information technology and tools to increase productivity and facilitate new forms of scholarship. For more information about JSTOR, please contact support@jstor.org.

Wiley, Royal Anthropological Institute of Great Britain and Ireland are collaborating with JSTOR to digitize, preserve and extend access to Man 


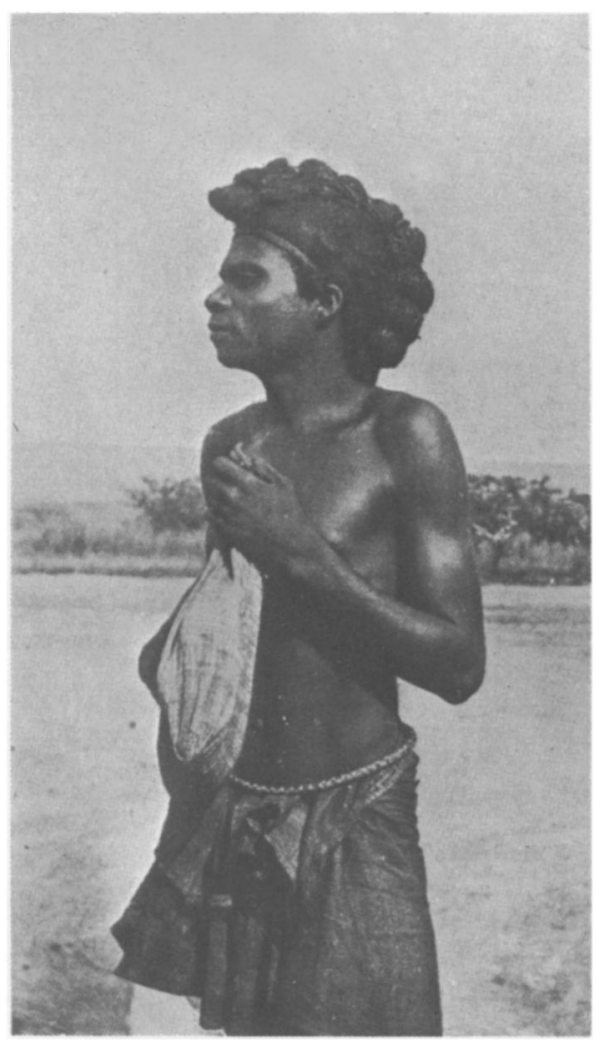

FIG. I.-MAN'S HAIRDRESS.

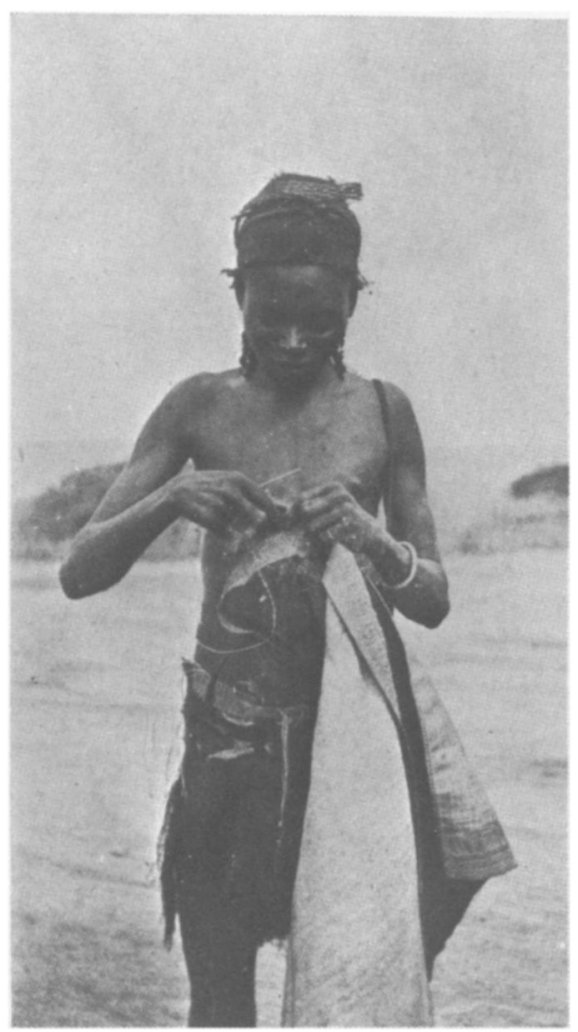

Fig. 2.-NOMBLNDA FMBROIDERY.

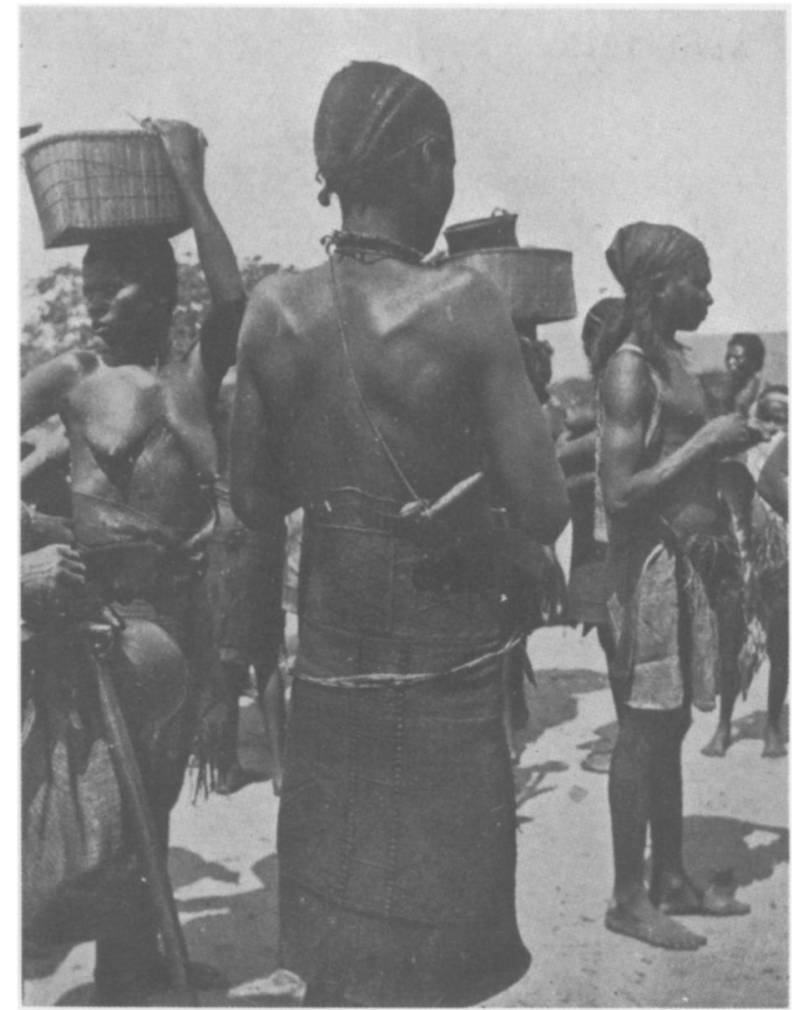

Fig. 3.-BUNDA WOMEN.

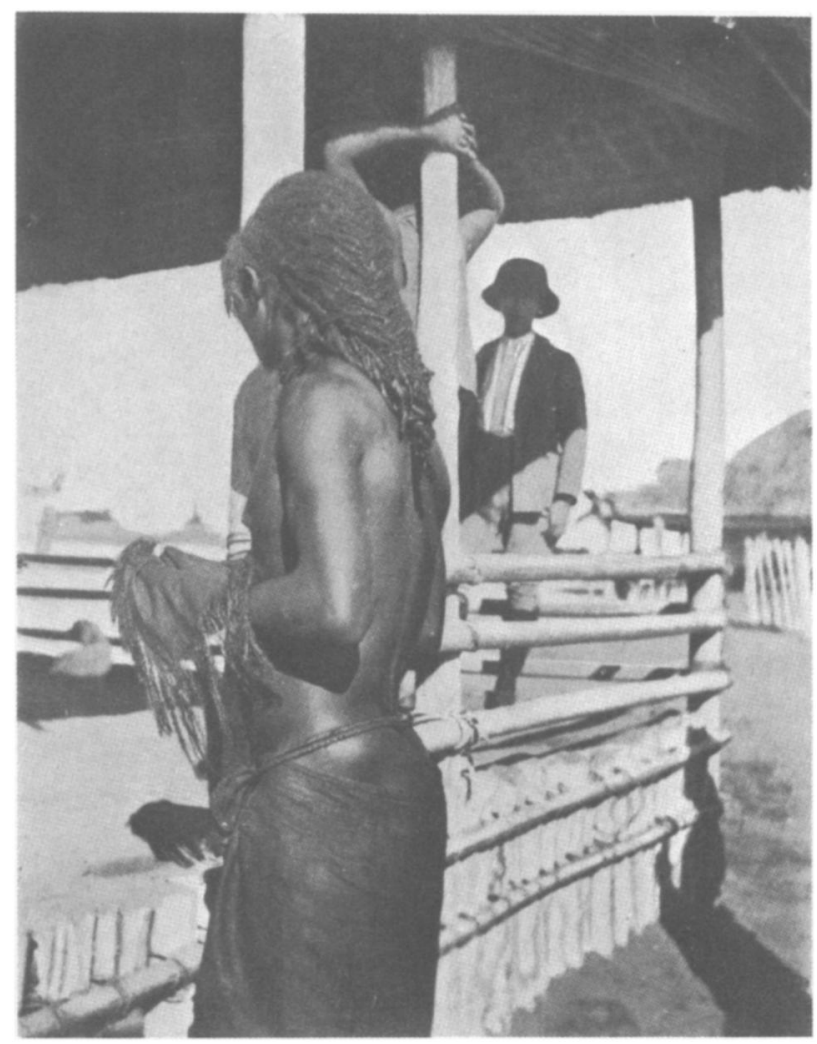

Fig. 4.-MAN'S HAIRDRESS.

THE NORTHERN BABUNDA

This content downloaded from 37.99.31.134 on Sun, 26 Jun 2016 13:26:29 UTC

All use subject to http://about.jstor.org/terms 


\section{ORIGINAL ARTICLES.}

\section{Africa: Ethnography. With Plate D. The Northern Babunda. By E. Torday.}

The Northern Babunda are an offshoot of the "Kimbundu" of Angola, 21 with whom L. Magyar has acquainted us. Babunda is the name by which they are known by their neighbours. Sir Harry Johnston says that -bunda is a root often associated with serf and helot tribes, but this can scarcely be the case with the free and powerful people in question; it is more probable that, as applied to them, the root is derived from the verb kubunda, to join together in partnership: or, better still, from kubunda $e$ dila kiantwadi, to combine for the purpose of trade. For we were told that the tribe came from the South, from a place on the Upper Kwilu called Moshinje, as traders, and, finding the country fertile and sparsely populated, the first comers induced other tribesmen to follow and to settle there; there was no war, no conquest, simply a peaceful penetration which ended with the expulsion or alsorption of the small aboriginal population. The date of this immigration can be fixed as being contemporary with the Jagga wars (XVIth Century), for we know that, when the Babunda (who had only acquired the habit of anthropophagy from the Jagga) freed themselves from that domination, certain sections of the tribe refused to give up cannibalism and emigrated." The Babunda, who live on the banks of the Lubue, told us that they used to be canuibals when they lived near the $\mathrm{K}$ wilu river, but on arriving at their present abode they lost so many people by disease that the fetishmen forbade the practice.

'The Northern Babunda call themselves Ambunu (sing. Mombunu). They are a fine, tall (average about $5 \mathrm{ft} .8 \mathrm{in.}$.), heavy boned, short legged, very dark-skinned race, with pleasaut features. They are friendly but shy, hospitable but very reserved. They are brave and never shirk a fight, though they prefer to keep the peace. They are very vain, the men more so than the women, and their taste for adornment is specially displayed in their hair-dressing. It is practically impossible to describe the various ways in which they arrange their abundant erop of hair, for new fashions appear daily, yet there are certain "standard" styles which are in general use. Some men wear heavy long tresses, often over a foot long and $t$ to 5 inches wide, hanging down their back; others arrange it in the shape of a fireman's helmet (as illustrated in Magyar), or again in the imitation of a cock's comb, formed by knots in a row from the forehead to the nape of the neck. Feathers, combs, false or real antelope horns, bones (sometimes human), or straw ornaments complete the coiffure. Beards and mustachios are generally only worn by chiefs; the former are, as a rule, tied up in a knot under the chin. Women plait their hair in several longitudinal ridges much more carefully in the east than in the western section. Boys frequently wear a small stick in the ear lobe, but grown-up people never; even the hole seems to close up again, for we could find no traces of it in adults.

With the exception of infants all Babunda are clothed; Manchester goods, though used in barter, are practically never worn, the clothing being made of three kinds of cloth : all lome-made from the fibre of the raphia palm. These are: Bunubun, plain cloth; Lubaua, cloth with interwoven pattern; and Lobubasa, cloth with embroidered black, lozenge-shaped pattern. The men's dress is generally composed of two pieces of either of the two first-named kinds; a smaller piece in front, from hip to hip, and a larger piece behind, held in place by belts made of hide, hark or fibre. The thighs are left bare and so is the greater part of the buttocks (in case of boys they are entirely uncovered), though some men wear a sort of tail about

* Magyar László : Utazások Dél--Afrikában. 
5 inches wide, made of cloth, hanging down their back from the middle of the belt. The cloth worn by men is frequently ornamented with tassels and fringes. Chiefs wear one long piece of cloth reaching down beyond the knee, and cover their heads with cloth.

The correct dress of women consists of two pieces of Lubawa sewn to a central strip of Lobubasa; this embroidered strip is worn behind straight down in the middle. Another embroidered strip forms the upper edge. In front the two ends meet above the navel (which must not be shown) and are held together by a large iron pin about 1 foot long; the lower ends of the vesture often stand apart. Unmarried girls wear their buttocks naked, matrons cover them. A Mombanda, to whom a reference will be found on p. 53, wears very short cloth, not over a foot broad. The garments of women are sewn with fibre, for which purpose native-made needles are used. Not only do the men weave the cloth, but they also embroider the Lobubasa for their wives; the very beautiful patterns are made from memory.

Ornaments of seeds, imported beads, bunches of aromatic herbs, irou, brass and 'oppor rings and bracelets are worn by both sexes; whistles, pigs' tusks, antelope's

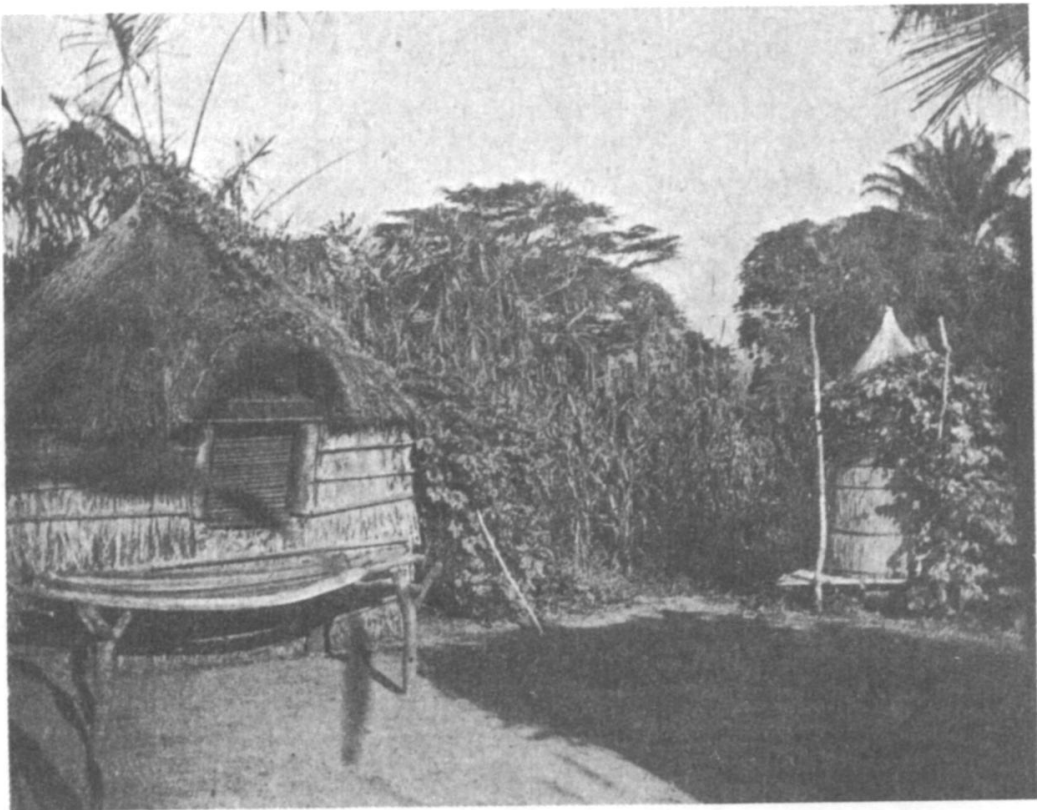

FIG. J.-HOUSE AND GRANARY. f e et and horns by men. The men do not $s$ car their bodies, but women indulge in long linear $\mathrm{kelo}$ id s which form lozenge patterns on the abd omen ; they also have initation betts s c a r r e d round the waist. Red and mauve clay mixed with palmoil are used as pigment; some women paint imitation mustachios and beards with soot on their faces; the meaning of this could not be ascertained.

The villages of the Babunda are very beautiful; some of them (like Alela) are situated in groves of palms while others (like Mokulu) spread out over an immense area, each hut being surrounded by the plantation of the owner; this is the practice in the majority of cases. 'The huts are extremely neat and picturesque. They are nearly square, and the walls, about 5 feet high, are made of grass or palm leaves; the latter are sometimes interwoven. The roof is of grass coming to a point about 9 feet high, and the summit is often ornamented with basketwork. The most characteristic feature is the entrance, which is 3 feet above the ground, and is flanked on the sides by round wooden columns, above which there is a semicircular porch, formed of the material of which the hut is built. The door is closed from inside with a mat. In front of the door, at a height of about 2 to 3 feet, [ 50 ] 
there is a platform made of palm-leaf midribs and supported on stout poles. The house of the chief is enclosed with grass walls pierced for a small entrance at a height of about $2 \frac{1}{2}$ feet. Apart from these orthodox houses there are some other rectangular huts with doors on the ground level; these are not kept so tidily as the others, and I suspect that they are the habitations of the slaves. Bachelors have each their own house; on marriage they have to build a new one in the village to which the wife belongs; a polygamist will thus have several houses situated in various villages, in each of which one of his wives lives with her children. Granaries are found in great numbers; they are cylindrical, much smaller than the dwelling-houses, and slightly raised on piles.

The principal occupation of the men is trade; all negroes are keen traders, but, with the exception of the Badjok, none give more of their time up to commerce than the Babunda. Great markets are held every eleventh day on some spot on the plains equi-distant from a number of villages, and both sexes muster to them in full force. Strangers, especially Europeans, are very unwelcome, as we experienced when we unexpectedly came across one in the course of our wanderings; all information concerning them was refused to us, but we were told that credit was never given. Were we suspected of wanting to make purchases on "tick"? Who knows! The principal articles of export are : agricultural produce (in very considerable quantities), palm oil, live stock and cloth ; imports : iron and slaves. Besides these big markets small markets are held in the villages every four days for the bartering of all sorts of commoaities.

Besides attending to business, the men weave, embroider, build the houses, obtain palm wine from the elais (Mano) and the raphia vinifera (Kwach), hunt, make baskets of a special kind (or plait them of string, see Sir Harry Johnston, George Grenfell and the Congo, p. 801), carve cups, and tight the battles of the village on the tribe.

'The women look after the children, cook, atlend to the fields, make baskets (different from those made by men), and fish with baskets in the small rivers. The men shoot fish with bows and arrows at night. attracting them by the flare of torches. The smith, who occupies a high social position, produces iron from the ore and manufactures the various implements; remarkable among these are the highly finished swords of a counter-changed ogee pattern. (See Journ. Roy. Anthr. Inst., 1907, PI. XVII.) They: say thät they have learned metallurgy from the Awana, a tribe on the left bank of the Kwilu.

Hunting is rather an insignificant affair, as the bigger kinds of game are absent in the northern part of the country, and the sportsmen have to be satisfied with such small fry as birds, rats, etc., which they shoot, in a stooping position, with bow and arrow ; further south, the whole village unites for an expedition and the game is bolted by firing the grass. The first man to hit the quarry is the owner, but the chief is entitled to one hind leg.

Flintlock guns are beginning to be introduced. The art of navigation is in its infancy, as the greater part of the country is devoid of rivers of any importance; on the banks of the Kwilu most primitive rafts of three or four logs tied together are propelled by paddles made of a stick to the extremity of which a few shorter sticks are tied crossways. There is always some war going on; it may be with a neighbouring tribe, between two villages, or even between two sections of the same village.

There is scarcely ever a great market held which does not end in a fight between two hostile factions. The bow and arrow are the weapons mostly relied upon (the same as used for hunting), but when the enemies come to close quarters the swords come into play, and they are terrible weapons too. When two villages 
have a difference, the signalling drum summons all males, including boys from the age of twelve or so; the chief takes command, and is advised by the old men. The two armies meet in the plains and, when they are within hailing distance, insult euch other with the vilest invectives. The war may drag on for some length of time, until the aggrieved village finds that the number of enemies slain is sufficient to compensate it for the injury or affront which was the cause of the hostilities. On the whole the casualties are small.

As the crops of the field belong to the woman who tilled it; it is her duty to feed her husband and her children. The staple food of the Babunda is millet (Masanga): cassava (Bolobol) and maize are only planted in smaller quantities. Bread is made by stirring the flour into boiling water till it forms a stiff pudding. For frying palm oil is used. The Babunda do not like to kill their fowls, so they are generally only eaten when they have died a natural death, when both sexes partake of them; occasionally, however, a wing is cut off a live animal so as to provide a festive meal; the chickens so amputated generally recover. Goats are killed on market days and sold in small pieces; these are preserved till they are high before they are consumed. Dogs and snakes, eaten freely by men, are taboo to women. The cooking is done by women, who practically never clean the vessels. The cook takes first what she wants and the rest is for her lord and master; in rase of a conjugal difference he is punished through the stomach. The bost always eats before his guest; meals are generally taken in the evening. C'annibalism is unknown. Kola nuts are used as a stimulant and to induce thirst; they are offered as a sign of goorwill to visitors. The only narcotics used are hemp and tobacco. The Indian hemp plant is found in quantities in the villages; tobacco, too, is grown near the habitations, probably to prevent pilfering. The latter is smoked and snuffed; the snuff is similar to that of the Bambala and is prepared in the same way.*

The following domestic animals are kept : chickens, goats, black pigs, dogs, and cats. Fowls are provided with tiny houses and pigs with enclosures, into which they are driven nightly ; cats and dogs share their master's house, while the goats have to shift for themselves. The latter are killed by a blow from the long wooden sword which is used by the Babunda in guise of a walking-stick. Castration is practised on chickens, goats, pigs, and dogs.

Domestic animals are used as currency : taking as the unit the bag of native salt, they represent: goat, 20-60; pig, 50-70; fowl, 1 . One salt is the same value as a roll of native cloth (Mobula). The value of cattle compares favourably with that of a wife (30 salti), a male (170) or female (200) slave.

Slaves are only possessed by men, who can sell them whenever they like, but. they cannot put them to death; their number is great and most of them seem to be Babunda. They may be so from birth, a child following its mother's status whatever the father may be, or they may have become so as a punishment for theft or rape or as a compensation for an unpaid debt. But we were assured that it was not the offender himself who was sold into slavery but his brother. The slaves are well treated and provided with wives by their owner, who often marries them into his own family ; though in theory their earnings belong to their master, in practice they generally receive a considerable part; this they can use to redeem themselves. A man is always responsible for any possible debts of his slave. Slaves are inherited like other property, a man's beir being his eldest living brother, failing him, his eldest living sister, failing her, the eldest sister's eldest son, and so on. Widows are irherited with other property, and so is the chieftainship, except that a female cannot assume that rank.

* Tourn. Roy. Anthr. Inst., 1905, p. 405. 
Few chiefs have any great authority, though the administration of justice lies in their hand. They receive no pay from the contending parties, but are generally disposed to tilt the balance of justice for a consideration. Blood revenge is recognised. The usual punishment consists of fines, of being sold into slavery; capital punishment is not inflicted openly, but a chief may kill an incorrigihle rogue by witcheraft. Drunkenness is not admitted as an excuse, and is not approved of ; the brother of a drunkard will forbid the palm wine sellers to supply him, and if they disregard his warning he will smash all their calabashes. In case of murder by all inhabitant of another village the community will claim an indemnity of ten slaves for the benefit of the victim's heir, and in case of non-payment, enforce it by war. A village will thus protect its members, the membership being acquired by birth in the village, or by marriage with one of the girls belonging to it.

To be a member of the tribe one has to be the child of a Mombunda woman. for a person considers himself akin to his mother's family, and not to his father's. Besides this kinship there is an age-kinship recognised between people born withiu the same period, the length of which we could not establish; this is an obstacle to marriage.

No persons who can trace a common ancestry are allowed to marry. If a youth desires to marry a girl, he will call on her parents and present them with some palm wine; he will pay several visits like this without ever mentioning the real object of his assiduity. If his courtship is viewed favourably by the parents. they will ask him to eat with them; this practically means consent, though the bride has the last word in the matter. Should she refuse, the disappointed lover will claim the return of his palm wine. If, however, things go well, the bridegroom will proceed at once to build $\boldsymbol{a}$ house in the girl's village, and, the bride price (30 salts) having been duly paid, the mother hands the bride over without any further ceremony. Some Babunda marry out of their tribe, but even then the rule is observed that the husband has to take his abode in the village of his elect. Polygyny is rare among the ordinary people, but chiefs generally have several wives. A man cannot marry his own slave. Both parties can divorce at will; if the husband repudiates his wife, he is entitled to no damages, except if his wife re-marries, when he has a claim on the second husband; if it is the wife who abandons her husband, her family have to reimburse the bride-price. In case of divorce, the first child goes with the father, the second with the mother, the next with the father, etc. If the wife dies before a child has been born, her parents refund the bride-price, or provide another wife gratis; it is the husband who decides if he wants the money or a bride; if, however, the deceased wife leaves a child, the husband cannot choose, but has to take another wife.

Virginity cannot be expected in the bride as girls are allowed to indulge freely up to the age of puberty. It is the custom of the country that about the period when the millet ripens (May) the young men of each village should club together to obtain a Mombanda. The Mombanda has to be a girl under the age of puberty, a stranger to the village, and she has to prostitute herself with all the young men in turns, but there are days when orgies take place and all the men have intercourse with her. On these special days the Mombanda's mother provides food and palm wine for the young men; it is she who receives the payment, which consists. for the term of its duration (two lunar months), of fifty to sixty "salts" per man. Not all young men contribute, as there are some who cannot afford it; only contributors enjoy the privileges, and it is "good form" to belong to this set. Not only does the fact that a girl has been a Mombanda not prejudice her chances of marriage, but it is considered a distinction; no girl can be a Mombanda more than once. Should she die while she is in this position, her village is entitled to heavy

$$
\text { [ } 53 \text { ] }
$$


damages. The girl, as mentioned before, wears a very short skirt, and her hut is distinguished from all others by being painted red and white in triangular patterns,

On the whole the moral code of the Babunda corresponds to that of civilised communities, though a distinct difference is made between a tribesman and a stranger; the latter is a legitimate object of exploitation and extortion. Yet hospitality is due to him, and a village which were not to offer it would acquire an undesirable reputation.

Adultery is considered a personal offence. 'The guilt' of an offender is frequently established by ordeal; this may be done in the old Bunda way, by giving a smail quantity of epumi (a decoction of the bark of Erythrophloum Guiniense) which, if it acts as a vomitive, proves innocence, while if it produces diarrhœe confirms the charge. Nowadays, however, another test, learned from the Bapinji, is used; the suspected person has to fish a pebble out of a pot of boiling oil; damaged skin proves guilt.

In case of witchcraft, the accused has always to undergo the test by epumi, which is then given in a deadly dose. It is to witcheraft (Molochi) that deaths without apparent reasons are attributed, that is to say, when they occur without violence or palpable disease.

A dying person is surrounded by his family. The corpse is ornamented with beads, wrapped in cloth, and buried without a coffin in the plains. The graves are marked with a stick and some pots, and no trouble is taken to keep them in a good state, consequeutly they are in a short time overgrown with bush. Yet the memory of the dead is cherished, and the first fruit is sacrificed on their graves, and no person will think of eating of the new crop before having satisfied the demands of the dead. The whole village laments the decease of an inhabitant for several weeks. The corpse is laid flat on his back' in the grave turning eastwards. The soul, $N^{\prime}$ tim (literally "liver"), dies with the body (the image appearing in dreams is the Doshi, the shadowy second self), and a Molochi kills his victim by devouring his soul. Sometimes it happens that the soul does not die with the body; then it turns into a ghost, Monchongo, and it is the duty of the magician (Boañ) to lay this. The Boa $\tilde{n}$ is a person of importance, and often a chief. He learns his trade as a boy, and has to pay two fowls to his teacher as soon as the apprenticeship begins; having acquired the more elementary part of his art, he has to pay a goat (the liver of which he eats), and finally he has to give his master thirty salts to be taught the deepest secrets of the profession. Then his power is great; he can manufacture the magical clay which, if smeared on the wooden images, will protect the owner of them, and he can kill a man, and is often asked to do so to satisfy some vengeance. He practices medicine, and is an adept at bleeding.

The Babunda are fond of music, and sing exceedingly well; as a matter of fact, better than any other tribe in the Congo. They never shout and scream in negro fashion, but use their velvety voices with moderation, and are capable of singing in perfect harmony; while they are doing so their bellies perform a circular motion corresponding to the time of the tune. We never heard the women sing. Their instruments are : the wooden whistle (a kind of wooden horn consisting of a simple hollow cylinder), ocarinas, the sanza, the musical bow with calabash resonator, drums, the friction drum, and the wooden gong. Specimens of all these have been collected for the British Museum. There is a specially interesting rattle, which I propose to call the switch-rattle, which consists of the midrib of a palm-leaf, half hollowed, and with teeth like a saw cut into the two edges; over these edges. a bundle of switches is drawn with a rapid motion, and the sound thus produced. This instrument is only played at funerals in front of the deceased's house.

$$
\text { [ } 54 \text { ] }
$$


Mutilations : Circumcision is general, and performed by old men on infants. All incisor teeth are filed.

Fire is now generally produced by flint and iron, a method learned from the Bambala.

The Babunda greet each other by one person saying, $\boldsymbol{J} u$ (peace), and receiving the answer, Ju. Then the first asks, Kalakala bile? (No war?), and the answer is the same.

The year is divided into the rainy and dry seasons (Vula and Kishu), and the months are called first of Vula, etc. The East is called sun-rise, and the West "where the sun goes to ground"; the sun is supposed to return to the East behind the sky during the night.

There is one village, Musoto, where the children play with little water-squirts male out of hollowed sticks; the inhabitants claim the invention of this toy, and do not like to sell any to strangers.

The Northern Babunda inhabit in the Belgian Congo the region between the middle course of the Kwilu and Lubue rivers, and are in contact in the North with the Badinga, the East with the Bagunde, the South with the Bapinji, and the West with the Bakwese and Southern Bambala.

E. TORDAY.

\section{Europe : Witcheraft.}

Witches' Fertility Rites. By M. A. Murray.

Murray.

The sexual ritual of the witches assumed enormous importance in the eyes 2 of their judges and of the contemporary recorders; consequently, the accounts of these acts are given with much greater detail than is generally the case with other parts of the religious ceremonies. Since the days of Reginald Scot it has been the fashion of all those writers, who disbelieved in the magical powers of the witches, to point to the details of the sexual intercourse between the Devil and the witches as proof positive of hysteria and hallucination. This is not the attitude of mind of the recorders who heard the evidence at the trials. "Les confessions des Sorciers, " que i'ay' eu en main, me font croire qu'il en est quelque chose : dautant qu'ils ont " tous recogneu, qu'ils auoient esté couplez avec le Diable, et que la semence qu'il " iettoit estoit fort froide : ce qui est conforme à ce qu'en rapporte Paul Grilland, " et les Inquisiteurs de la , foy." " "It pleaseth their new Maister oftentimes to " offer himselfe familiarly unto them, to dally and lye with them, in token of their " more neere coniunction, and as it were marriage unto him." $\dagger$ "Witches confessing " that the Devil lies with them, and withal complaining of his tedious and offensive " coldness, it is a shrewd presumption that he doth" lye with them indeed, and that " it is not a meer Dream." $\ddagger$

It is this statement of the physical coldness of the Devil which modern writers adduce to prove their contention that the witches suffered from hallucination. Yet in trial after trial, in places far removed from one another, and at periods more than a century apart, the fact is vouched for with just the small variation of detail which shows the actuality of the event. When the witch admitted having had sexual intercourse with the Devil, in a large proportion of cases she added, "The Devil " was cold and his seed likewise." These were women of every class and every age, from young girls to old women, unmarried, married, and widows. Such a mass of evidence cannot be ignored, and in any other subject would obtain credence at once; but the hallucination theory, being the easiest, appears to have obsessed the

\footnotetext{
* Boguet : Discours des Sorciers, p. 68.

$\dagger$ Cooper: Mystery of Witchcraft, p. 92.

$\ddagger$ More : Antidote against Atheism, p. 241. 